\title{
Erratum to: Spatial Trends and Factors Affecting Mercury Bioaccumulation in Freshwater Fishes of Washington State, USA
}

Callie A. Mathieu - Chad V. Furl • Tanya M. Roberts • Michael Friese

Published online: 24 March 2013

(C) Springer Science+Business Media New York 2013

Erratum to: Arch Environ Contam Toxicol

DOI 10.1007/s00244-013-9882-8

The original version of this article unfortunately contained a mistake. The spelling of the first author's name was incorrect. It should be spelled "Callie Mathieu".

The online version of the original article can be found under doi:10.1007/s00244-013-9882-8. 